\begin{tabular}{l} 
RCCS \\
\hline Annual Review
\end{tabular}

\section{RCCS Annual Review}

A selection from the Portuguese journal Revista Crítica de Ciências Sociais

$3 \mid 2011$

Issue no. 3

\title{
The Detained-Disappeared: Civilizational Catastrophe, the Collapse of Identity and Language
}

\section{Gabriel Gatti}

Translator. Sheena Caldwell

\section{(2) OpenEdition}

\section{Journals}

Electronic version

URL: http://journals.openedition.org/rccsar/270

DOI: $10.4000 /$ rccsar. 270

ISSN: $1647-3175$

\section{Publisher}

Centro de Estudos Sociais da Universidade de Coimbra

\section{Electronic reference}

Gabriel Gatti, « The Detained-Disappeared: Civilizational Catastrophe, the Collapse of Identity and Language », RCCS Annual Review [Online], 3 | 2011, Online since 01 October 2011, connection on 02 May 2019. URL : http://journals.openedition.org/rccsar/270 ; DOI : 10.4000/rccsar.270 


\section{Gabriel Gatti}

University of the Basque Country

\section{The Detained-Disappeared: Civilizational Catastrophe, the Collapse of Identity and Language}

This article proposes the concept of catastrophe as a starting point for the construction of appropriate representation strategies for phenomena of extreme social violence, exploring the case of the forced disappearance of individuals in Argentina and Uruguay. The analysis begins with a paradox: this process represents the culmination of policies for the construction and management of the population in post-colonial America, and is simultaneously applicable to the most completely formed products of this policy, namely individual citizens. Due to this paradox, the forced disappearance of individuals implies unsolvable problems in terms of interpreting the characteristic identity and language of the "civilizing process," the individual-citizen and direct representation. Thus, disappearance situates identity and language within the terrain of catastrophe, demanding that our representation strategies be reconsidered.

Keywords: Argentina; catastrophe; civilization; disappeared; identity; representation; state terrorism; Uruguay; social violence.

This text explores problems that are difficult to resolve, associated with understanding what happens to social life when it is removed from the parameters that define it within the terms of modern conventions, in particular the convention that binds words to things and representations to facts. There are many situations nowadays in which this convention is broken, some banal and others extreme. This article focuses on one of the latter cases, namely forced disappearance, an extreme situation that forces us to seriously reconsider the relationship between memory, social life, identity and representation.

In order to address this extreme situation, I will make use an old concept, that of catastrophe. After introducing the concept, I intend to analyse the sense in which forced disappearance is a catastrophe, since it affects two essential assets, identity and language. Following this, I will present certain efforts to understand and exorcise this catastrophe, ${ }^{1}$ which have proved fruitless since they demonstrate that in the face of extreme violence it is necessary, above all, not to abandon representation but instead to review our strategies for

\footnotetext{
* Article published in RCCS 88 (March 2010).

${ }^{1}$ Other efforts are analysed in the book which contains the results of the research on which this article is based (Gatti, 2008), referring to various projects undertaken between 2005 and 2008 in Argentina and Uruguay, financed by the University of the Basque Country mobility scheme and the Basque government. This text analyses the results for the two countries, in particular Argentina.
} 
representation. The text ends with a brief proposal concerning the means by which this may be achieved.

\section{Catastrophe: (Brief) theoretical notes}

There are facts that are associated in a stable manner with meanings and also facts that are completely dissociated from meaning. This dissociation may occur on an occasional or a lasting basis. In the latter case, we are confronted with problems involving the representation and accommodation of situations affected by this dissociation: if the dissociation between facts and meanings stabilises, we are faced with a social catastrophe. I will explain the concept in terms of a sequence: if degree zero is normality (facts united with meanings), it is followed by three distinct degrees of dissociation of facts and meanings resulting from trauma, a significant event and, on the boundaries of what is conceivable, catastrophe:

1. The destabilisation that occurs with trauma is profound but provisional, since there are institutional practices that can regulate maladjustments and are able to ensure that after destabilisation a new balance is established. After a certain period of time, things return to their original place and normality is restored. The death of a loved one is a trauma; mourning, when it comes to an end and is resolved, is the practice that enables us to manage its effects.

2. The destabilisation that follows a significant event is profound and intense, to the extent that when it happens the disruption is absolute but short in duration. As it is so intense, there is no category capable of describing it. Thus the event is unique and nameless, but rapidly fades. Few examples can therefore be cited: sudden bursts of pain, powerful revolts or intense pleasure, none of which leave any traces behind.

3. Catastrophe is stable instability, a permanent maladjustment between words and things converted into a maladjusted structure. "Catastrophe is a dynamic that creates a dismantling without founding an equivalent logic as part of its articulatory function" (Lewkowicz, 2004: 154). The cause of the catastrophe does not disappear: it is the permanent exception, the abnormality of the norm, a permanent state of mourning. It is a trauma that is not resolved, an event that endures, ambivalence normalised. "This time, the flood is here to stay" (ibid.). Forced disappearance is an example of a social catastrophe, although there are also other, less serious examples such as the identity 
of the "undocumented" or certain situations involving precarious employment. Following a social catastrophe, a very problematic social space is constructed, which is defined by the breakdown of conventional relationships between social reality and language when this breakdown is consolidated, and in particular when consolidation creates permanent difficulties in terms of representing what takes place in the territories defined by the breakdown. ${ }^{2}$

\section{Forced disappearance. A catastrophe in context}

In an attempt to demonstrate the analytical usefulness of this concept in terms of understanding social situations defined by extreme violence, it will be applied to a concrete case, the forced disappearance of individuals and the figure of the detained-disappeared, within a particular social and historical context: the process of civilization as manifested (in exacerbated form) in Argentina and Uruguay. Within this context, the device of disappearance (Calveiro, 2004) and the figure it produces, the disappeared person, manifest themselves, in my view, as a device that aims at and a figure that embodies the destructuring and rupture of the most prototypical product of modern subjectivity, the individual-as-citizen.

\subsection{Gardeners, the construction of societies and individuals within the civilizing process in the}

\section{Latin American Southern Cone}

As is the case with almost all of Latin America, Argentina and Uruguay are the result of the dream of civilization. There, "the motives [of the coloniser] [...] in founding new cities in the territory they had just conquered and destroying the old indigenous cities they had encountered en route corresponded to a new plan, that of inventing a new Europe" (Blengino, 2005: 19). These were places imagined as having emerged out of nothing, like the

\footnotetext{
${ }^{2}$ This concept is formulated on the basis of notions of linguistic and psychological catastrophe. The former may be understood, following George Steiner and Alvin Rosenfeld, on the basis of the effects that extreme phenomena create on language. This is the case with Auschwitz, which, for Steiner, subjects language to such a profound crisis that he asserts it "is beyond language" (1967). For Rosenfeld, it constitutes a veritable "linguicide," a case of the "death of language" (apud Grierson, 1999). The latter may be approached through the work of René Kaes, for whom "a psychological catastrophe occurs when the usual methods of dealing with the negativity inherent to a traumatic experience prove inadequate, especially when they cannot be used by the subject due to the particular qualities of the relationship between the inner traumatic reality and the surrounding environment" (1991: 98). In other words, it happens when a situation cannot be understood through the mechanisms for understanding structures which this situation has destroyed.
} 
work of shaping a desert populated on the basis of a plan, a void filled thanks to careful gardening (Bauman, 1987), so that within it (1) a population can take shape (Foucault, 2006), (2) the Lettered City can be constructed (Rama, 1998), and (3) the subject that makes up the resident population of this city, the individual-as-citizen, can be configured.

\section{Shaping the population}

Since the $18^{\text {th }}$ century, government has been exerted over populations, not territories. This is biopolitics, "the means" - states Michel Foucault - "by which [...] the practice of government has attempted to rationalise the phenomena represented by a group of living beings formed into a population: problems relating to health, hygiene, birth rate, longevity and races" (1990: 119). This government of populations has its own genealogy and its own protagonists.

The genealogy of the government of populations can be located with no great difficulty when combined with the idea of creating a society. I will not dwell on this issue; it is sufficient to state that society is a recently invented form of social life (Donzelot, 1984; Kaufmann and Guilhaumou, 2003) that features in the collective imaginary of its many preceptors - from republicanism to anarchism and from liberalism to socialism - as a territory for corrective action (an arena for politics and rights) and observed action (an arena for sociologies and anthropologies). The pen of these preceptors was so mighty that as part of their social project they were able to create what they had dreamed of: a society, a "strategic notion" (Donzelot, 1984: 77), which served to create, mould, model and modulate things and people.

Things and people, that is, that conformed to the logic of the nation state and the individual-as-citizen, the protagonists in the narrative. I do not intend to enlarge on this either (Gatti, 2007): it is enough to recall that the metaphors that shape our subjectivities are a direct legacy, on a collective level, from the nation state and, on an individual level, the individual-as-citizen. Both are closely related and as such are similar, even though they give an impression of rivalry and conflict. Whether they like it or not, they have always shared the same parentage (modernity) and the same logic: both are organised, coherent, stable figures - like the state - and indivisible - like the individual. They are always uncontaminated and have their own place; they are never dirty or disorganised. Both constitute the model for modern life, to the extent that they have become our producers of solidity (Lewkowicz et al., 
2003: 171). They constitute "our song," the melody that seduces us, the only way we have of viewing social life. I am not referring only to empirical references or administrative realities but to our "pan-institutional providers of meaning," our "general principles of consistency" (ibid.: 31 and 65), which, for the moderns, is equivalent to nothing less than basic geometry (Moya, 1984).

\section{The construction of the Lettered City}

However, things are not always the same everywhere: modern governamentality which, since the $18^{\text {th }}$ century, has taken populations to be its object and product, and the nation state and the individual-as-citizen its favoured creatures, undoubtedly extends everywhere but in different ways. Thus, the task of colonising reality has its own historicity and territoriality: although they may appear to do so, the history of the invention of society in Europe and the history that accounts for this process in Latin America do not completely coincide. In the case of the former, battles were fought against the feudal state and the gamekeeper (Bauman, 1987), the stylised exponent of the pre-modern "gardening culture" and the subject with the power to administer his own domains, explains Bauman, frugally and freely. In the face of this policy, the "rule of the knowledgeable and knowledge as a ruling force" (ibid.: 67) was established in old Europe. However, it was not the same in America: the state did not concern itself with replacing the old gamekeepers but envisaged its task as that of installing gardeners, firstly to make civilizations grow and afterwards to maintain and take care of them.

In Latin America, unlike the European norm according to which the city emerges after a lengthy process of development or, in some cases, by imposing itself in the face of the resistance of the feudal structure, the starting point is the ideal. Thus civilization is not a result, but a beginning.

In essence, gardening is as hard a task as any other form of sociological engineering and is equally powerful and, without doubt, well intentioned and even beautiful. In addition, it involves orderliness: the gardener, as we know, is in charge of planning the garden and also of clearing the weeds and keeping what lies within the walls immaculately tidy, with admirable patience and persistence:

Modern culture is a garden culture. It defines itself as the design for an ideal life and a perfect arrangement of human conditions. It constructs its own identity out of distrust of nature. [...] 
Apart from the overall plan, the artificial order of the garden needs tools and raw materials. It also needs defence - against the unrelenting danger of what is, obviously, a disorder. The order, first conceived of as a design, determines what is a tool, what is raw material, what is useless, what is irrelevant, what is harmful, what is a weed or a pest. (Bauman, 1989: 92)

Ángel Rama has explored the idea that the Latin American city was born out of the execution of an erudite and scholarly plan. In this city, things fulfilled words, in an age in which words and things had begun to connect or, at least, to connect in accordance with modern pacts. Latin America, an empty continent in the collective imaginary of the colonizer, was a promising place for a good start to a life in the company of this newly created couple: "Latin American cities basically became creations of the human mind, since they were inscribed in a cycle of universal culture in which the city became the dream of an order that could only take shape in the land of the New Continent" (Rama, 1998: 17). Virgin land, tabula rasa, ex nihilo creation, a perfect world dominated by representation. New Spain, New Helvetia, New León, New Paris... The same as before, but without errors.

This is the modern order of representation, that is, a prototype transposed onto reality. A "planning principle," in Rama's words, governed this translation of the model to the terrain. Even today, because they were efficient, the results of this work of representation (since it is representation that combats the void to be colonized) are striking: cities were born, states created, imaginaries devised, filled with utopias, defined by the plan by which they were designed and by the clauses with which it was embellished, including the obligation to keep the land free of plagues. This is relevant to the topic addressed here, namely the catastrophe of forced disappearances: it influenced a future that would continue to think in terms of civilizing, preserving and cleansing. At the end of the day, this future, our present, is not so far removed from these origins.

Under modernity in the paroxysmal state, society submitted to the gaze of the engineer/gardener is seen as "an object of administration, as a collection of so many 'problems' to be solved, as nature to be 'controlled', 'mastered', 'improved' or 'remade', as a legitimate target for 'social engineering', and in general a garden to be designed and kept in the planned shape by force" (Bauman, 1989: 18). Who sustained this dream? Rama refers to auditors, notaries, geographers, lawyers, clerks, bureaucrats... but the list can be extended to include scientists and priests (Blengino, 2005), and, at its limits, to various shades of the military. 


\section{The making of the civilized individual}

The subject who lives in this beautiful modern garden is the individual. Its management partly depends on his good relationship with the machinery for registration and socialisation that has existed in nation states since the $18^{\text {th }}$ century (the census, schools, identity documents, personal records...). It also depends on the response he can give to the list of questions attached to the civilizing process, and to its demands for good manners and selfconsciousness (Elias, 2000). This subject has a history, however much it has become ahistoric nowadays and considered a "sociological universal that accompanies the human condition" (Béjar, 1988: 15). This is not the case; it is, on the contrary, something that has been recently invented:

The group identity of the single person, his we-, you- or they-identity, played a much too important role, compared to the I-identity in the social praxis of the ancient world to give rise to a need for any universal concept for the single person as a quasi-groupless identity. (Elias, 2001: 158)

Elias offers clues for an approach to the social origins of this single subject that was, and is, the individual-as-citizen. In The Civilizing Process he analyses how the work of civilization takes place in conjunction with another task whose scope is only superficially more modest, the birth of the modern individual. Its origins may be traced by following a path in which, as external constraints increase, the level of self-consciousness rises. José María González García summarises the process well:

This transformation presupposes a process of self-formation on the part of the individual, the transformation of his emotional system, the containing of emotions, a change in the precepts of 'good manners' at the table or at any other gathering of 'good society', the development of a great capacity for psychological observation of the self and others [...]. It creates a calculating type of man, always on the defensive, repressing his spontaneous emotional reactions, a great observer and understander of his own self and an expert in the psychological observation of the human being. (2001: 47-48)

Civilization translates into psychologisation on the level of the affective economies, or rationalisation, which amounts to the same thing. Society ultimately finds its ideal partner on the level of personal subjectivities. Weber and Freud are united through the civilizing process. Society finds its balance - arrangements dictated by need coincide with directives for action:

[C]onstraints through others from a variety of angles were converted into self-constraints, [...] the more animalistic human activities were progressively thrust behind the scenes of people's communal social life and invested with feelings of shame, [...] the regulation of the whole 
instinctual and affective life by steady self-control became more and more stable, more even and more all-embracing. (Elias, 2000: 365)

Thus society reveals itself as a grouping of self-controlled individuals: chaste, decorous, with good table manners, endowed with a psyche - a civilized psyche - and a growing level of internal differentiation, individuals who do not defecate or salivate in public, who eat nicely, all in the same way. They are the ideal inhabitants of the Lettered City. They are not machines; they often take part in public life and believe in citizenship and even in the possibility of change and improvement. Argentina and Uruguay are full of people like this.

This is the purity of the "American way" of implementing the civilizing process. Places emerged from the language of civilization, which, consumed with a kind of feverish nominalism, rechristened everything it found: "Names for minerals, plants and people were changed and invented. Shrubs and grasses were scientifically classified. The clergy also changed people's names and used numbers to show the success of their evangelical enterprise" (Blengino, 2005: 56).

The Lettered City, as Ángel Rama so aptly calls it: life as the result of writing (and the census and the judicial machinery and the national identity document). Foucault and Elias have outlined Argentina and Uruguay. Others have peopled them with individuals. These individuals have been devastated by the mechanism of disappearance.

\subsection{The mechanism of disappearance. Elias in the concentration camp}

The background to forced disappearance is a society based on a rhetoric in which the discourse of ex nihilo creation and that of elimination of surplus are played out and in which both the construction of what fits into the project and the disappearance of the dysfunctional and conflictual are of equal importance.

This is not simply a matter of the analyst's interpretation; those responsible for the 1976 coup d'état in Argentina also pompously christened themselves the leaders of the "Process of National Reorganisation" and mobilised the old imaginaries of the nation states in the region as states formed from the dialectic of order and disorder, civilization and barbarism (Blengino, 2005). They were the continuation of the work that began with the Wilderness Campaign, when the indigenous population of what is nowadays Argentina was annihilated.

But how could this happen in countries considered by everyone - and especially by a significant number of those born in them, including the present author - to be educated, 
enthusiastically shaped by literary references, with two capital cities that are more European than many actual European capitals since they are a synthesis of them? It is certainly tempting to argue that torture and, on a higher scale of brutality, forced disappearance, contradict the rules governing the progress of civilizing processes, that they are a throwback, an expression of what remains to be domesticated, that "still more civilizing efforts" are required (Bauman, 1989: 13). Yet, contrary to the hypothesis of a breakdown in civilization or the sudden emergence of barbarism, the hypothesis that what we are witnessing is a paroxysm of rationality is perhaps more accurate. In other words, the dictatorships of the 1970s, rather than violating Argentine and Uruguayan societies or representing exceptions in their history, actually revealed that they contained a not insignificant number of bodies "readily prepared to serve the extermination machine" (Vezzetti, 2002: 152).

This, then, is the hypothesis: the forced disappearance of individuals is not barbarism but rather an exacerbated form of modernity. This is, in fact, the proposition on the basis of which Zygmunt Bauman (1989) analyses the Holocaust, when he argues that the logic of this phenomenon is not alien to our enlightened modernity, both in its most spectacular manifestations (scientific rationality and the construction of the idea of citizenship) and its most banal (the gardener's painstaking task of clearing ground, the dedicated doctor's relationship with a patient...). The Holocaust was an enormous "sociological laboratory" (ibid.: 12) which sent out many signs, not of the dangers of a return to pre-social barbarism, but of the "hidden possibilities of modern society" (id.). This devastation is the apotheosis of the civilizing dream: The Holocaust was "fully in keeping with everything we know about our civilization, its guiding spirit, its priorities, its immanent vision of the world - and of the proper ways to pursue human happiness together with a perfect society" (ibid.: 8).

The Wilderness Campaign in Argentina, forced disappearance, Auschwitz... all these phenomena are "legitimate resident[s] in the house of modernity; indeed, [they] would not be at home in any other house" (ibid.: 17) and there can be no doubt that they all bear a strong family likeness to modernity.

This hypothesis helps to make sense of what took place in the 1970s in Argentina and Uruguay as a radicalisation of the modern project. Thus, Hugo Vezzetti is right when he affirms that "the [Argentine] dictatorship was as much an outcome as an eruption" (2002: 16). 


\subsection{The paradox of the detained-disappeared, a local invention}

Within this context of the civilizing process, the population policies and the (re)construction of the strictly planned Lettered City, from the $16^{\text {th }}$ century to the 1970 s, to the present day, the machinery has worked with automatisms: we are confronted with a state developing a population policy, operating as a gardener. Its keepers strive to ensure that Eden continues, and that if anything veers off course it will be contained and reorganised. The objective still remains to shape the wilderness through civilisation, taking care to ensure that what has been planted grows well. Yet not everything is a matter of history repeating itself. There are two major new features: the secret detention centre, the epitome of biopolitical space, a place for extreme control over life (Calveiro, 2004; Gatti, 2008), and the disappeared, an abysmal catastrophe. I will focus here on the latter.

In this case, power was exercised as it always has been, over entities that defied the order. It was no exception - or rather, it was, since it had one glaring peculiarity: the entities subjected to forced disappearance were the most refined products of the process of civilization, card-carrying citizens, who were rational, educated and clean (or sullied by their own choice). The perfect fruits of modernity were the ones that would be ripped apart by the machinery that had brought them into being.

This enormous force, the civilizing force, creates this landscape. And, if necessary, it unmakes it. It takes as the object of its work - and I would even say that this is historically unprecedented and thus theoretically fascinating and morally terrible - its own product, the modern, rational individual, whose identity is referenced with civic and administrative credentials. It takes the clean, self-conscious individual of the nation state, of liberal citizenship, the subject found on the psychoanalyst's couch, and unmakes it. This is, I repeat, a true invention, so much so that it merits a name for the paradox from which it is created, "the paradox of the detained-disappeared," which may be formulated thus: (1) forced disappearance is one of the tools of population construction and management which belong to the civilizing/modern order; (2) forced disappearance is applied to the most complete products of the civilizing/modern order. Hence, the civilizing routine was applied to the most finished product of civilization. It is an inverted civilizing machine, a machine for decivilization, which is not the same as barbarism.

Paying attention to the situation at the time - the military forces trained in the School of the Americas, the doctrine of national security and the generalised production of the 
internal enemy, the Nazi, Spanish or Vietnam experiences - involves factors that would doubtless explain a great deal concerning this episode. The truth must lie out there. Yet none of them can account for the sub-liminal horror that forced disappearance has caused and causes: probably unintentionally, an instrument that destroys meaning has been invented. A catastrophe: "The beasts were painting La Giaconda when in reality they were killing flies with a paintbrush [...]. They did unbelievable things, they separated identities from bodies, that was what they did." ${ }^{3}$

\section{Forced disappearance as a catastrophe of identity and language ${ }^{4}$}

The disappeared person is an emergency, a singularity, an unintended consequence, something unforeseen. He is a fragmented individual; a body separated from a name, a consciousness removed from its physical support, a name separated from its history, an identity deprived of its citizen cards. He is a "body to which things happen," says the daughter of one. Pure vulnerability.

Confronted with this, "the word senses the threat of its own exhaustion [...]. The threat of exhaustion damages it [...] in terms of its essential and original power, the power to name" (Gómez Mango, 2004: 15). Therefore disappearance and its figures can only be defined by using a set of semantically diffuse terms: chupado, ${ }^{5}$ separated, dissociated; borrado, ${ }^{6}$ a subject impossible to record within the repertoire of structured existence; chupaderos, ${ }^{7}$ places of detention into which the subject was absorbed, abducted almost, by the mechanism of disappearance. The disappeared, Gómez Mango also says, is someone abandoned, a "living-dead," a "corpse robbed of death," someone "always present by their absence" (2004: 17). ${ }^{8}$ And this absence is a state, not a situation": "The category of

\footnotetext{
${ }^{3}$ From an interview with a member of the Argentine Forensic Anthropology Team.

${ }^{4}$ The quotations which follow are taken from interviews held, as part of the abovementioned research (see footnote 1), with members of the Argentine Forensic Anthropology Team and the Association of Former Detained-Disappeared. In some cases they were taken from the archives of the Buenos Aires Memoria Abierta Foundation.

${ }^{5}$ Missing person [T.N.].

${ }^{6}$ Wiped out, eliminated [T.N.].

${ }^{7}$ Secret military prisons [T.N.].

${ }^{8}$ Gómez Mango, based on Arendt, proposes to include the disappeared in the list of the forsaken of the world: the precarious, the clandestine, the undocumented, refugees, pariahs: "The notion of the forsaken [...] seems to me to be the best one to describe and understand the psychological suffering experienced by these pariahs of modernity" (2004: 101), an "inner experience of feeling oneself radically expelled from humanity" (ibid.: 8).

9 The author illustrates this difference by using the expressions "se es desaparecido" (the verb "ser" indicates a state or an essential quality) and "se está desaparecido" ("estar" indicates a situation or condition) [T.N.].
} 
disappearance implies a presence-absence that endures over time" (Kordon and Edelman, 2005).

We are confronting a new state of being, in a previously unknown place. We had thought that within the architecture of existence it would not be possible to find a place between life and death, and that if it did exist (purgatory, limbo, ghosts, spectres...), it would be of short duration. But disappearance invents a perpetually unstable space, a kind of permanent liminality. Besides, it is unresolvable: there is not even the certainty of the death of the disappeared subject to bring closure.

It is clear that this is an enormous catastrophe, a permanent dissociation: an entity that had had the status of individual-as-citizen is expelled beyond the pale, where previously tramps and scum were sent and, like them, converted into an NN. ${ }^{10}$ They cease to be citizens and become the disappeared. Therefore, the verb desaparecer (disappear) is not conjugated with the verb estar [to indicate a temporary condition] but with the verb ser [to indicate a state]: “When they tell me 'tu estás desaparecido', it's not actually 'estás desaparecido' [you are someone who has disappeared], but 'és um desaparecido' [you are one of the disappeared]." Nothing less than a new state of being is created ("You are one of the disappeared, neither living nor dead," "A non-person, a thing that doesn't know whether it exists or not"). An unprecedented status, "a new abyss."

It is true that forced disappearance has occurred in other chapters of history, for example, during the 1941 Nacht und Nebel (Night and Fog) campaign (Amnesty International, 1983) - which would appear to be the direct historical antecedent for the device - and during the Spanish Civil War. It still happens today in camps such as Guantanamo, or in Argentina itself, in the indigenous zone of Tucumán, where the policy of forced disappearance was particularly virulent and the effects as terrible as those in urban areas. In any of these cases, the strategy, systematically applied, is, in addition to being perverse, also effective.

But it is not the same thing.

It is not a question of partiality, far less of comparing horrors. I repeat my hypothesis to argue the point: in the civilized capitals of the Southern Cone, forced disappearance radically

\footnotetext{
${ }^{10} \mathrm{NN}$ is used to mark the tombs of unknown individuals or mass graves. It means nomen nescio ("name unknown") although due to a translation rather than a semantic error, it is translated as "Nenhum Nome" or "No Name." In Argentina in the 1980s numerous skeletons appeared in NN graves in public cemeteries, identified as those of disappeared individuals.
} 
affects and destroys the forms of representation of identity and of the subject, whereas in the other places cited it is plausible to resort to devices which, in terms of local traditions, explain the existence of bodies without identities or names without bodies. ${ }^{11}$

What is being demolished here is the mainstay of our means of understanding identity. It is the individual who is destroyed: he loses his name, has no territory and is separated from his history. This is the catastrophe: things no longer have words to give them consistency. The words that exist are no use: we are confronted with a figure represented as being without a place ("The disappeared leave no trace, they create a void"), corresponding to no recognisable entity, simultaneously absent and present ("[With them] absence becomes presence"), without logic ("Disappearance is an attack on logic. It creates a sense of the absurd"), and without a body ("It is a body without an identity and an identity without a body"). It is a nebulous territory between life and death, a true swamp: words and things melt and their unity is destroyed. A catastrophe.

Or two catastrophes: one which has ravaged the modern architecture of identity and one which has ruined the possibility of representation. I will approach the former via the efforts made to reorder the remaining fragments of disappeared identities in order to reunite bodies and identities, and the latter through the task of bearing witness to what took place in the camps. Many organisations have helped give shape to one or the other. I have chosen two of the most representative to illustrate this work: the Argentine Forensic Anthropology Team (Equipa Argentina de Antropologia Forense), which works on the status of the fragmented identity, and the Association of Former Detained-Disappeared (Associação de Ex detidos-desaparecidos), which is drawing up strategies to give a voice to the horror.

Both efforts aim to bring order to catastrophe, to introduce (imaginary) order into the chaos (of the imaginary) which forced disappearance creates. A great deal is achieved: contemplating disappearance, being able to make a statement ... but the efforts almost always end in despair at their impossibility or the recognition of the incommensurability of

\footnotetext{
${ }^{11}$ Such as in Tucumán, in North Argentina, where people speak of the inausentes, as the Argentine researcher Mecky Vega informed me. Disappearance is conceptualised there by invoking traditional figures ("he was taken by a Familiar Spirit," "he was taken by the Dog"), some of which date back to the time of the Conquest. It is feasible to explore the hypothesis that in these traditions figures exist that can help to deal with forced disappearance and its consequences, figures that dull the pain caused by forced disappearance, which cannot be contained when it occurs in places that do not have these shock absorbers. It is not a matter of this being an advantage, since it indicates that the horror is not exceptional but part of a continuing sequence of affronts: now, as in the past, "the armed men" come.
} 
the catastrophe in relation to the resources that can be mobilised to contemplate it, which amounts to the same thing.

\subsection{The catastrophe of identity and its (impossible) exorcism}

Little remains of the disappeared: there is information on their condition before they acquired this status, and the (incomplete, insecure) testimonies of their passage through the secret detention centres. In material terms, very occasionally a body without an identity remains, otherwise, there is an identity without a body, the name of someone known to be disappeared without any trace of their body. It may be the case that some bureaucratic remains survive - the advantage of having been swallowed up by that civilizing machine, the state - such as packages of papers, duly stamped trails testifying to the momentary or final emergence of someone from the catacombs of the machinery of disappearance and of their entry into the more visible and better known areas of the state apparatus prolific in institutions and people: the staff of the mortuaries who bury and testify, the doctors and nurses in out-patients who attend to a young woman who has been shot and write the report for the public hospital records, the experts and police on night duty who routinely photograph bodies found in the street and add the reports to the files, the state archivists who preserve a typed copy of this body without a name, the duty magistrates who verify and attest to the fact that the body belongs to "nobody" and that the destination of this nonidentity is the mass grave in the public cemetery. But the most common scenario is that not even these traces remain and it is only possible to access - a strange and perversely redundant term - information that indicates that others had previously requested information about those who are now the disappeared: records of habeas corpus requested by mothers, copies of statements of disappearance submitted by spouses denied the status of legal subject by the state for the purpose of inheritances, purchases, sales... blocked by the impossible status of their partners ... Nothing else.

Here, the things that comprise a modern identity appear in fragments. In this task of fragmentation, the dismembering of a subject, lies the theoretical key, according to many agents, to the forced disappearance of individuals:

1. Firstly there is the shattering of what is seen as the ontological unity of the human being, that which unites a body, and one only, with a name and one name only. The EAAF (Argentine Forensic Anthropology Team) states: "What clandestine repression did was to 
transform one thing into two; the identity and the body are the same thing, they have to be the same thing but at a certain moment it is as if you arrive at a particular place, a stopping point where the two things that form one are dissociated." Terrible is the work of this machinery which decomposes the unity, naturalised in the modern subject, between body and consciousness, the condition of our ontological balance. It works by cutting up, dividing and dissociating this complete individual. It does nothing less than rupture the coexistence, within an entity that is always the same in itself (the semper idem of identity), of a body, which is mutable but whole, and a consciousness, which is mutable but essentially one. What emerges from this disintegration is a new figure: the disappeared, a subject, but a shattered subject, and an identity, but a pseudo-identity. A new state of being, a body separated from a name, a consciousness removed from its physical support.
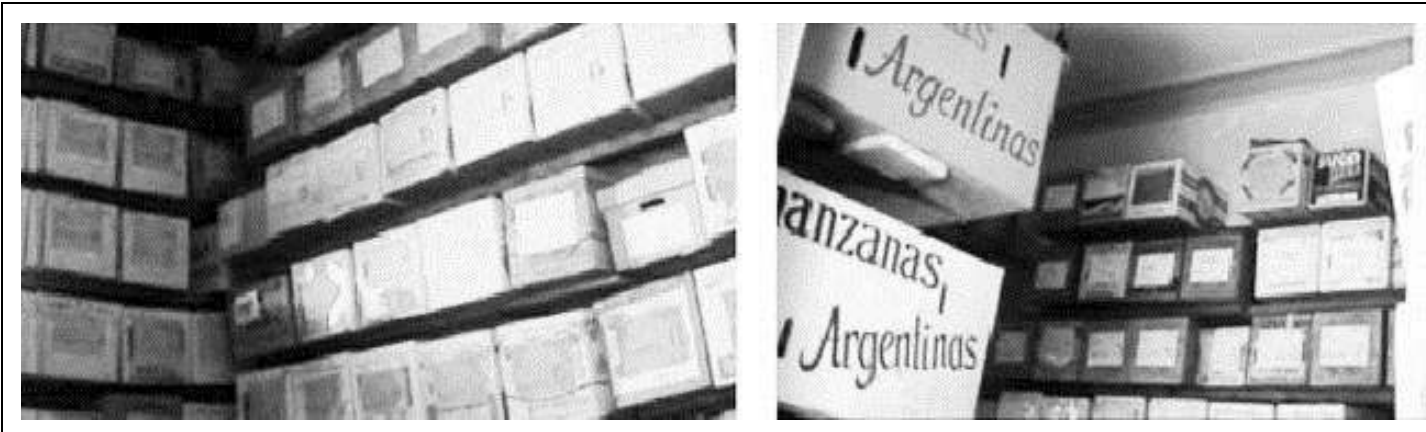

Skeletons dissociated from their names at the EAAF head office in Buenos Aires, Argentina. Stills from the film Nietos. Identidad y memoria (Ávila, 2004). The following is an excerpt from a statement by a member of the EAAF, taken from the same film: "What we have still been unable to do in all cases [looking at the boxes] is to establish a meaningful relationship that would allow us to restore the basic relationship we all have between our identity and our body. Amongst other things, what state terrorism did in these cases was to dissociate, to separate identities from bodies. The identity remains in the air, and the body stays here. The aim of this work is for things not to remain the way they left them, and they left them like this [pointing to the boxes], with the identities separated from the bodies."

2. The machinery has shattered this name and body, formerly united in an identity associated with a continuity, that of the family narrative, conveyed by parentage: "What happened, the dismantling of the rights of individuals through disappearance, murder and the kidnapping of children, now young people and still disappeared, has led to a breakdown in the human system of parentage, it is a massacring of bonds and a fracturing of memory" (Lo Giudice, n.d.).

3. Finally, the machinery has shattered the relationship of the individual, as a body and a consciousness linked to a family history, with the administrative unit that gives him meaning 
as a citizen, namely the state. He has been deprived of the rights of citizenship and described in terms similar to those used by gardeners when weeding land: rabble, ungovernable, classe dangereuse, vagabond, nomad, riffraff, mobile vulgus, outlaw, racaille, linyera, ${ }^{12}$ subversive... nameless people.

These three interpretations of the fragmentation created by forced disappearance allow us to measure the depth of the catastrophe that this phenomenon brings to our understanding of identity. In the light of this, the reaction is to deal with the disaster by remaking what has been destroyed, in other words, by re-associating what has been broken up by disappearance, the pact between words-as-names and things-as-bodies. This is what the Argentine Forensic Anthropology Team does, working with what remains of this pact, to reconstruct and restore meaning. It works within the limits of what is possible. It re-makes the work of the machine by inverting it and whereas, as I argue, the latter has de-civilized, it strives to re-civilize. It seeks to rebalance the relations between body and name (to recover identity), reconstitute the individual by reinstating him within his family history (creating mourning) and restore his status as a citizen (officially registering him as dead). It involves a lot of work, using the logic of the bureaucratic machinery, which gives and takes away identity, by inverting it:

- From birth, an individual is given a number and an identity, no one escapes this. [Without this] you are not part of the state, you are not an individual in full possession of your rights. What happens is that this method of population registration is used [in cases of disappearance] in a different way.

- [GG] And you are basically doing the same thing ...

- Yes, but in reverse.

With one aim, to reconstitute the shattered identity:

- [GG] Identifying means restoring identity?

- Of course. If I break this cup and have to stick it back together again, what do I do with the pieces? What was it before? A cup, so I have to end up with a cup again, if I've got all the fragments... I never have them all but it has to be as close to a cup as possible.

\footnotetext{
${ }^{12}$ A word used in Argentina to describe a tramp.
} 


\subsection{The catastrophe of language and (impossible) testimony}

You are what we once were, we are what you will be.

(Inscription at the entrance to the old cemetery of

Orereta, Guipúzcoa)

Giorgio Agamben proposes that the Nazi concentration camp should be considered a space constructed on the basis of the logic of exception, the principle by which the law orders its own transgression (1998: 20). When exception occurs, it gives rise to two situations. Firstly, there is strict demarcation (exception takes place in a separate world), and afterwards, a specific language for this world that is inadequate in the world it contradicts, the world in relation to which it is an exception. This language has an awkward grammar and stammers: exception requires babble. These two facts coincide in the few reports that have emerged from the secret detention centres, the chupaderos in the jargon of the repressive machinery itself, places where all connections with the exterior are severed and the detaineddisappeared enters a space where daily life takes place "in the deepest confines of cruelty and insanity" (CONADEP, 1987: 59). It is a place with rules that break the Rule: there, one exdisappeared told me, "the laws of gravity were abolished," and another said, "the rules from outside did not apply. They overstepped all the limits." A third individual explained: "What is it that can't be conveyed? The deaths? The disappearances? The torture? All of this can be understood. I mean, understood mentally. What can't be understood? The anomy, you can't understand the lack of rules."

In her account of the time she spent in the Escola de Mecânica da Armada (Navy Mechanics School, known as ESMA), the most infamous of all the chupaderos, Pilar Calveiro describes it thus: "There is a very clear feeling that you are in a different dimension, in a world apart." Cut off from the outside world, the concentration camp is, she says, a "real unreality governed by other kinds of logic" (Calveiro, 2004). Graciela Daleo, another survivor of the ESMA, testifies to the "walks" outside the chupadero into which she had disappeared: "I told myself I was here but in reality I wasn't in this world." There is a world switched on, with clear rules, and a world switched off, which is invisible, dark, disappeared, and exceptional.

Out of this exceptional space, this fringe of reality in which norms are suspended and order is defined by this suspension (Agamben, 2008), emerge the agents of testimony - the former detained-disappeared. They are the ex-disappeared who occupy a complicated place 
that is difficult to deal with in a world that copes badly with the non-standard and, suffering as it does from horror vacui, abhors a lack of meaning. They exist in a disturbing space between two worlds, a paradoxical limbo, an ambivalent purgatory ("We still don't belong anywhere"; "Sometimes I felt like a ghost, nobody listened to us, nobody believed us"), places as aberrant as they are abnormal and always impossible. The ex-disappeared inhabits a difficult place. How can they continue to cling to an identity, the identity of the disappeared - the inhabitants of a black hole - if, when they emerge from the hole, that identity no longer exists? How can they protest and continue to speak as the disappeared if, precisely because they can now speak, they are no longer these people?

The first step towards exorcising this catastrophe is to find a common name to describe this difficult collective situation: the "appeared," "the reappeared disappeared," "ghosts," "the disappeared who appear." The second step is to give substance to this common name by constructing a communal arena for speech, a communitas, in this case the Association of Former Detained-Disappeared, a community support base in Argentina for many exprisoners which makes their group identity plausible: "A place of our own," "A bit like our own union, the survivors' union." A shared but complex place, a springboard for the staging of a shared stigma, an open sore ("We are an open wound, we are the ones who bear the marks of the camps on our bodies," "We are the ones who escaped death," "We are the ones who have come back from the void"). And once the common name and shared place have been established, the third step is to speak through them.

This speech takes the form of testimony. For many it is almost a mission: that of the terstis who mediates and conveys information, a kind of medium (Agamben, 2008: 17). ${ }^{13}$

But what does the witness bear witness to? And how? Agamben, basing his ideas on the work of Primo Levi, analyses the relationships established between two types of individuals from the camps: those who succumbed and those who saved themselves. The latter, the survivors, can talk about the camp, but only in relative terms: those who have lived through

\footnotetext{
${ }^{13}$ According to Agamben (2008: 17) the witness is the terstis, the intermediary ("the person who, in a trial or lawsuit between two rival parties is in the position of third party"). The superstes is the person who has lived through something and survived and can therefore bear witness to it; and the auctor is the person who makes the testimony emerge, a narrator or, in other words, the person who narrates a fact which they have survived with the intention of providing information, even if this fact is something that cannot be survived, is not reportable and cannot be recounted (cf. $148 \mathrm{ff}$.).
} 
it cannot - they have looked on the Gorgon. ${ }^{14}$ The former bear witness and represent; the latter, who are mute, are represented. The former are locked into the absurdity of the impossible: they speak of something they have approached, but not touched. This is what Agamben calls "Levi's paradox": "The Muselmann is the complete witness" (2008: 82, 150, 165); "I bear witness for the Muselmann" (ibid.: 165). Adapted to our context, this would be: (1) the disappeared is the complete witness; (2) the ex-disappeared speak in place of the disappeared.

Thus, those who can bear witness have no words and those who have words have nothing to say. Despairingly, as some of them recognise, "The onus is on the disappeared and they cannot bear witness, they cannot speak. And those of us who have in some way been in the same places as the disappeared, what we are doing, seems to me to be ... false," "they are the witnesses". Prisoners of paradox, they realise that those who can truly bear witness do not have the word and those who have the word have nothing to say: "Testimony appears here as a process that involves at least two subjects: the first, the survivor, who can speak but has nothing interesting to say; and the second, who 'has seen the Gorgon', who 'has touched bottom', [...] has much to say but cannot speak" (Levi, 2008: 120).

\section{Conclusion: Representing catastrophe}

What can those who have not experienced the extremes of horror, even though they have come close to it, speak about? How can they account for this catastrophe of language? Some of the ex-disappeared opt to turn the situation on its head, speaking of the void that opens up between the disappeared (the fact in all its intensity) and themselves, the witnesses (who can represent the fact). It is within this void that the testimony is situated, and this is the tension it expresses: the terrible tension to which forced disappearance submits language. Someone accurately said that that the testimony of extreme situations is the discourse that gives "linguistic expression to the unnameable" (Sucasas, 2002: 333), not through the representation of the truth it contains but because it is the best response to the impossibility of achieving this in these situations, of the despair at being unable to tell, of not

\footnotetext{
${ }^{14}$ The Gorgon is the Greek goddess who had the power to kill those who looked at her. Levi says: "We, the survivors, are not the true witnesses [...]. We survivors are [...] an anomalous minority: we are those who, by their prevarications or abilities or good luck did not touch the bottom. Those who did so, those who saw the Gorgon, have not returned to tell about it or have returned mute, but they are the 'Muslims', the submerged, the complete witnesses [...]. They are the rule, we are the exception" (1989: 83-84; my italics).
} 
having words. It gives words - truncated words - to a place from which words have been banished. Thus, the survivors "bear witness to a missing testimony. [...] they must bear witness in the name of the impossibility of bearing witness" (Agamben, 2008: 34).

It is therefore not surprising that one of the ex-disappeared, feeling impotent, should ask at the beginning of his testimony, "How can I structure this delirium?" and another admit "If I had to recount what I believe was the experience of the condition of the disappeared ... I would have to stay silent, I would have to stop talking." Nor is it strange that they think that what happened is utterly unrepresentable:

The experience you have lived through can be told, but I think there is a small part that [...]. There is something that lies beyond this, that has another register.

The balance of my experience has to do precisely with the difficulty in conveying it, there is something that is impossible to transmit...

The narratives that Vezzetti (2000) calls the chupadero narratives, that is, the reports emerging from the secret detention centres, have an unusual structure. When the exdisappeared return from the camp, they believe they have been reborn: they are once again instated, reincorporated into the things we call "normal," whether this means the idiotic bureaucracy of an ordinary prison or a penitentiary that clearly has the status of an exception. Reality is restored and "words reappear," one survivor explains. But the words that reappear cannot bear witness to the experience, since they refer to something else. They have emerged from a buried world into the light of another. Each has its own logic, but they are untranslatable. What functions in one does not function in the other. The experience finds no place in the recognised language.

There are no references for the impossible. However much is translated in the objective and objectifying nature of a testimony intended to be faithful to what took place, or attempts are made to steer the negative that cannot be inscribed into a framework of socially shared rationalisation within which an abnormal fact may be inscribed (for example, the language of political explanation or the more slippery framework, also supplied with convenient causalities, of attributing moral perversion to the oppressor), however much this is achieved, a latent despair always remains in those who speak. Firstly it is the despair that what is being recounted is being told badly ("There is something that is not comprehensible in this experience"; "There is something here of an experience, I won't say ... I don't want to call it ineffable, but it is"), and it is also despair at recounting only the surface ("[When you 
tell it] you leave out everything you felt when you experienced it, as if you were transforming it into a material thing"). This is the testimony of the ex-disappeared: the despair at not being able to represent. They skimmed the surface of the catastrophe and that, some say, "cannot be explained. How can this enormity be explained!" And in the camps, "words disappear too."

Clandestine repression constructed a place for the exercise of power, probably applied through the banal actions of bureaucrats who exerted repression as a matter of routine. The secret detention centre helped this power to grow into something disturbing, beyond the control of the bureaucrat. It was a place of exception, where language did not work, which could scarcely be spoken about, about which it was only possible to stammer and stutter. The testimony is the formula for doing so. It gives words to the catastrophe that is forced disappearance: it marks the lapses, the holes, the cracks in the representation. Its spokespeople are the agents who live in this anfractuosity shaped from the rupture between words and things, and who, in order to talk about it, develop a language that speaks of the impossibility of speaking.

If catastrophic situations exist, we, the prisoners of horror vacui, want to master them and saturate them with meaning. When faced with forced disappearance this is what forensic anthropologists and the ex-disappeared do: the former want to restore the conventions on which our idea of identity is based (BODY + NAME) and the latter want to restore the conventions on which representation is based (THINGS/WORDS). Nevertheless, both end up only partly achieving their aim: they come close to achieving responses in terms of what happened, which is fundamental in many areas (justice, truth), but remain distant from responses to what a catastrophe is. It is the detained-disappeared; it therefore requires a reconsideration of how identity is created and language is constructed when the modern meanings of both terms are confronted with issues that call them into question.

Translated by Sheena Caldwell

Revised by Teresa Tavares 


\section{References}

Agamben, Giorgio (1998), Homo Sacer: Sovereign Power and Bare Life. Trans. Daniel Heller-Roazen. Stanford, CA: Stanford University Press.

Agamben, Giorgio (2008), Remnants of Auchwitz: The Witness and the Archive (Homo Sacer III). Trans. Daniel Heller-Roazen. Brooklyn, NY: Zone Books.

Amnesty International (1983), Desapariciones. Barcelona: Fundamentos.

Ávila, Benjamín (2004), Nietos. Identidad y memoria (film).

Bauman, Zygmunt (1987), Legislators and Interpreters: On Modernity, Post-modernity, and Intellectuals. Ithaca, NY: Cornell University Press.

Bauman, Zygmunt (1989), Modernity and The Holocaust. Ithaca, N.Y.: Cornell University Press.

Béjar, Helena (1988), El ámbito íntimo. Madrid: Alianza.

Blengino, Vanni (2005), La zanja de la Patagonia. Los nuevos conquistadores: militares, científicos, sacerdotes y escritores. Buenos Aires: FCE.

Calveiro, Pilar (2004), Poder y desaparición. Los campos de concentración en Argentina. Buenos Aires: Colihue.

CONADEP (1987): Nunca más. Buenos Aires: EUDEBA.

Donzelot, Jacques (1984), L'invention du social. Essai sur le déclin des passions politiques. Paris: Fayard.

Elias, Norbert (2000), The Civilizing Process: Sociogenetic and Psychogenetic Investigations. Malden, MA: Blackwell.

Elias, Norbert (2001), The Society of Individuals. New York: Continuum.

Foucault, Michel (1990), Tecnologías del yo. Barcelona: Paidós.

Foucault, Michel (2006), Seguridad, territorio, población. Buenos Aires: FCE.

Gatti, Gabriel (2007), Identidades débiles. Una propuesta teórica aplicada al estudio de la identidad en el País Vasco. Madrid: CIS.

Gatti, Gabriel (2008), El detenido-desaparecido. Narrativas posibles para una catástrofe de la identidad. Montevideo: Trilce.

Gómez Mango, Edmundo (2004), La desolación. De la barbarie en la sociedad contemporánea. Montevideo: Ediciones de la Banda Oriental.

González García, José Mạ (2001), “Metáforas de la identidad. Nosce te ipsum," in Juan Manuel Iranzo \& Rubén Blanco (eds.), Sobre las identidades. Lecciones Carlos Mendive (1998-1999). Pamplona: UPNA.

Grierson, Karl (1999), "Indicible et incompréhensible dans le récit de déportation," La Licorne, 51, 97129. 
Kaes, René (1991), "Rupturas catastróficas y trabajo de la memoria", in Jeanine Puget \& René Kaes (eds.), Violencia de Estado y psicoanálisis. Buenos Aires: Centro Editor de América Latina.

Kaufmann, Laurent; Guilhaumou, Jean (2003), "Présentation," Raisons Pratiques, 14.

Kordon, Diana; Edelman, Lucía (2005), “Efectos multilaterales de la represión," Brecha, 1010.

Levi, Primo (1989), The Drowned and the Saved. New York: Vintage International.

Lewkowicz, Ignacio et al. (2003), Del fragmento a la situación. Notas sobre la subjetividad contemporánea. Buenos Aires: Altamira.

Lewkowicz, Ignacio (2004), Pensar sin Estado. La subjetividad en la era de la fluidez. Buenos Aires: Paidós.

Lo Giudice, Alicia (n.d.), "Derecho a la identidad." Consulted November 2007 at http://www.abuelas.org.ar.

Moya, Carlos (1984), Señas de Leviatán. Madrid: Alianza.

Rama, Ángel (1998), La ciudad letrada. Montevideo: Arca.

Steiner, George (1967), Language and Silence: Essays on Language, Literature, and the Inhuman. New York: Atheneum.

Sucasas, Alejandro (2002), "Primo Levi: el nacimiento del testigo," in Reyes Mate (ed.), La filosofía después del Holocausto. Barcelona: Riopiedras.

Vezzetti, Hugo (2000), "Representaciones de los campos de concentración en Argentina," Punto de Vista, 68.

Vezzetti, Hugo (2002), Pasado y presente. Guerra, dictadura y sociedad en la Argentina. Buenos Aires: Siglo XXI. 